BOLLINGEN SERIES $X$

ofo 


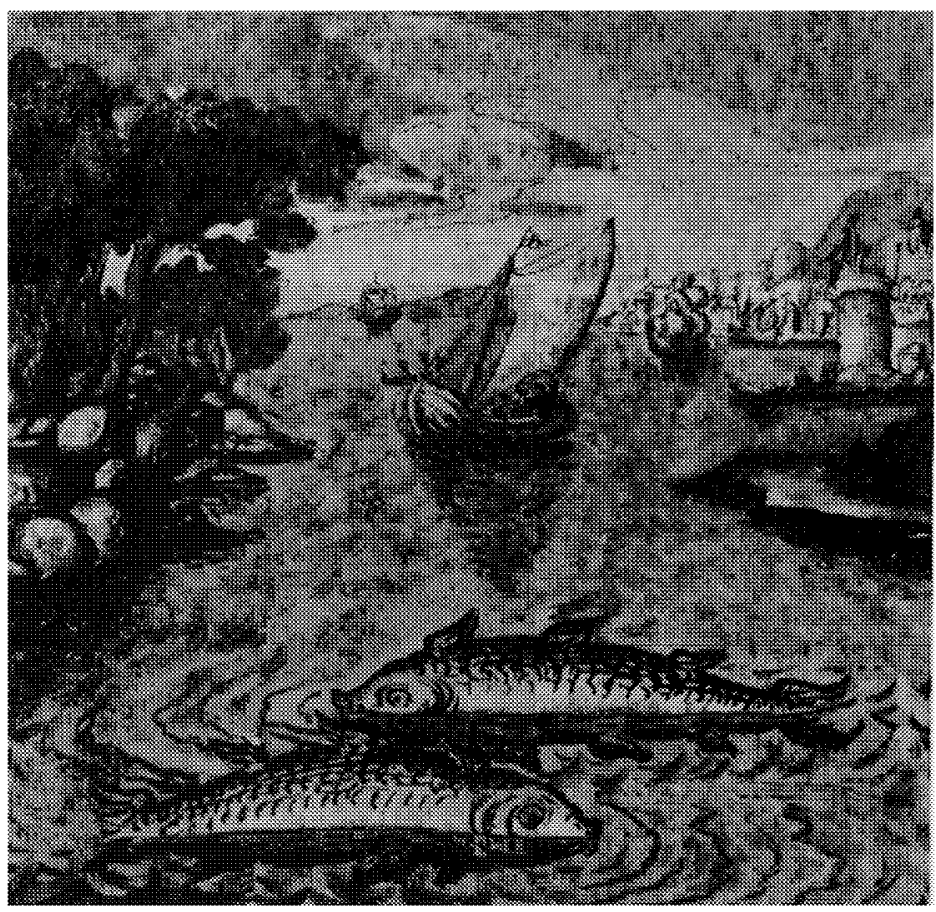

"The Sea is the Body, the two Fishes are the Spirit and the Soul"

From a manuscript of The Book of Lambspring 
M. ESTHER HARDING

\section{PSYCHIC ENERGY}

\section{Its Source and Its Transformation}

With a Foreword by $C$. G. Jung

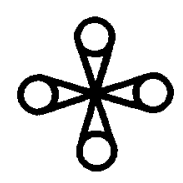

BOLLINGEN SERIES $X$

PRINCETON UNIVERSITY PRESS 
Copyright 1947 by Bollingen Foundation, Washington, D.C.

New material in second edition copyrigbt $\mathbb{C} 1963$ by Bollingen Foundation, New York, N.Y.

Published by Princeton University Press, Princeton, New Jersey

THIS IS THE TENTH IN A SERIES OF BOOKS SPONSORED BY BOLLINGEN FOUNDATION

First Edition: Psychic Energy: Its Source and Goal, $194^{8}$

Second Edition, revised and enlarged, 1963

First Princeton/Bollingen Paperback Edition, 1973

$$
\begin{array}{lllllll}
11 & 13 & 15 & 16 & 14 & 12 & 10
\end{array}
$$

Princeton University Press books are printed on acid-free paper and meet the guidelines for permanence and durability of the Committee on

Production Guidelines for Book Longevity of the Council on Library Resources

Library of Congress Catalogue Card Number 63-104I 2

ISBN 0-691-01790-5 (paperback edn.)

ISBN 0-691-098 1 7-4 (hardcover edn.)

Printed in the United States of America

Text designed by Andor Braun 